\title{
New generation of social entrepreneurs: Exploratory research and cross case study analysis of new generation of social enterprises
}

\author{
Monika Tkacz*
}

\begin{abstract}
Summary: The extensive development of social entrepreneurship transnationally is being increasingly shaped by youth entrepreneurs from the so-called millennial generation. The newest reports unveil that social entrepreneurship has become a youthful movement engaged in developing social initiatives worldwide. The article is an exploratory and pilot research with an objective to verify the profile of the new generation of social entrepreneurs. The author applies qualitative, narrative and cross case study analysis of the young social entrepreneurs (under the age 30) giving insights into 71 social ventures from 14 European countries and 5 overseas. The study focuses on e.g. innovation types, fields of operation, capacity of social impact, market orientation and revenue capacity models, founders' biographical traits and their opportunity recognition patterns. The findings discover a few leading features within the members of the new generation of social entrepreneurs such as, inter alia, increasing market orientation, high utilization of technological solutions (especially in the area of social exclusion) or approximate level of pull and push factors that engage young entrepreneurs to create social enterprises.
\end{abstract}

Keywords: new generation, social entrepreneur, social entrepreneurship, social innovation.

\section{Introduction}

We live in the fast-moving times and discontinuous changes of the new age of knowledge, information and access. At this juncture, there are opportunities for radical improvement, solutions and new approaches to complex and long lasting issues [Andersson, Curley, Formica, 2010]. We can observe widespread entrepreneurial activity and technology that are central to countries' economic growth. In addition, politicians, business leaders and members of society call for endeavours that focus on social and environmental objectives leading to social health and overall socioeconomic development of countries. Some of these objectives are pursued by governments and by semi-public organisations. However, there is no clear boundary concerning which social and environmental problems should be the responsibility of governments and which problems may, at least partly, be left open for the market for private and other non-governmental organisations [Bosma, Schøtt, Terjesen, Kew, 2016].

As a result, there are blurring boundaries between public, private, and non-profit sectors leading to formation of various hybrid social enterprises in the quest for more effective solutions to national and global issues [Kaplan, 2013]. GEM special report on social

\footnotetext{
* Monika Tkacz

MIK, S. Coop.

Ibarra Zelaia Zelaigunea, 2, 20560 Oñati, Gipuzkoa e-mail: mtkacz@mondragon.edu
} 
entrepreneurship ${ }^{1}$ shows that social entrepreneurial activities are taking root in both developing and developed nations. The early-stage social entrepreneurial activity, measured by the percentage of adults between the age of 18 and 64 who are currently trying to start a social purpose business is at a global average of $3.2 \%$. By comparison, the rate of startup commercial entrepreneurship averages 7.6\% [GEM Consortium, 2017b]. It must be underlined that the social purpose businesses do not exceed the commercial activities, however, there is a growing trend of young people in particular that facilitate their passion for social change into new social enterprises. According to the newest report [Bosma, Schøtt, Terjesen, Kew, 2016] there are more social entrepreneurs in the age between 18-34 than commercial entrepreneurs in every global region, except for Latin America and the Caribbean (see Figure 2; operational stage). It indicates high contribution of millennial generation (born between mid-1970s and 2000s,) to socioeconomic transformation and it allows to consider the social entrepreneurship to be a global youth movement.

The discovered trend in the youth entrepreneurship has been already globally discussed by, inter alia, Ashoka ${ }^{2}$, World Economic

GEM is the Global Entrepreneurship Monitor, and it is the world foremost study of entrepreneurship. GEM is the richest resource of information on the subject, publishing a range of global, national and, special topic' reports on an annual basis. The special report on social entrepreneurship is the largest comparative study of social entrepreneurship in the world, based on interviews with 167,793 adults in 58 economies in 2015 and published in 2016 [GEM Consortium, 2017a]. Ashoka is a network of more than 3,300 world's leading social entrepreneurs (Ashoka Fellows) that implement system-changing solutions to human and environmental problems [Ashoka, 2017].
Forum $^{3}$, Skoll Word Forum ${ }^{4}$, or EFESEIIS ${ }^{5}$ Not surprisingly, the article makes an attempt to observe the discovered phenomena in youth entrepreneurship and to verify key patterns and characteristics of the new generation of social entrepreneurs from transnational perspective. The author conducts pilot research and analysis of social enterprises of millennial generation presented by Forbes in the last 2 years [Forbes Europe, 2016; Forbes Europe, 2017; Forbes Global, 2016; Forbes Global, $2017]^{6}$. The author adapts two selective criteria: (1) the formation year: 2013-2017, (2) and the age of the founders: 18-30. It resulted in a sample of 71 social enterprises from 14 European countries (e.g. Poland, England, Germany, France or Spain) and 5 overseas (US, India, Kenya, Botswana, Nepal). The main study objective is to discover key leading features that shape the profile of new generation of social entrepreneurs. The study, however, is limited to the well prospering and promising social ventures of the young generation detecting characteristics of the best practices within the youth social entrepreneurship. The research discovers (1) main biographical traits such as age or male/female component, (2) the most frequently chosen innovation types, (3) revenue capacity models, (4) predominant fields of operations (5) and the main motives that push or pull young entrepreneurs to apply their ideas to social enterprises.

World Economic Forum was established in 1971 as a not-forprofit foundation to engages the foremost political, business and other leaders of society to shape global, regional and industry agendas [World Economic Forum, 2017].

4 Skoll World Forum on Social Entrepreneurship was established to accelerate entrepreneurial approaches and solutions to the world's most pressing problems by uniting social entrepreneurs with essential partners in a collaborative pursuit of learning, leverage, and large-scale social change [Skoll World Forum, 2017].

Research project for 'Enabling the Flourishing and Evolution of Social Entrepreneurship for Innovation and Inclusive Societies' supported and funded by European Commission [EFFESEIIS, 2016].

Forbes conducts exhaustive assessment of worldwide social enterprises on the basis of specific key quantifiable metrics such as revenue, social impact, inventiveness or social benefit. 
For the purpose of better understanding of the concept, the author starts with a brief background description of new approaches in the area of solving socioeconomic issues, transformations in social innovation patterns or social entrepreneurship boundaries on the basis of broad literature review. The author gradually introduces the evaluating profile of a new generation of social entrepreneurs presenting a theoretical overview of their specific features or characteristics. To provide proof and explore the concept the author investigates a sample of social enterprises worldwide applying a compilation of two methodological approaches: Benadusi's and Sapienza's variables and analysis approach [2012] and Condie's and Cooper's [2015] categorization model (see Figure 3). The findings of the pilot research are a solid base for further and deeper research and a valuable source of initial estimation of the current patterns and future pathways within the youth social entrepreneurship.

\section{Innovation for common good}

Nowadays, societies more intensively than ever articulate the drive to make a change in a form of innovation innovation that engages, motivates and mobilizes people and resources for progressive impact [World Economic Forum, 2015]. According to Andersson, Curly, Formica [2010] the impulses for action cannot in a general sense come 'from above' and a fundamental feature of the current era is the scope it creates for bottom-up initiative. Innovation is less frequently pushed by experts and technocrats and more often pulled by the real needs of people, and of society, to produce better responses to real issues, which are further facilitated in cross-sectoral actions. Social innovators share, taste, redefine, develop and apply innovations faster than ever before as the open source technologies allow individuals to innovate from anywhere quickly and rapidly [Kaplan, 2013]. More and more often social or economic gaps and risks or issues are not just something to be avoided but, on the contrary, they result in cutting edge solutions, products, services or programmes invented by 'socially sensitive' entrepreneurs leading to social transformation, economic growth, social change and new market opportunities [Global Opportunity Network, 2017; Nicholls, Murdock, 2012].

Social innovation is cross-disciplinary and occurs within and between existing institutions including business, public sector services and community organisations [Kaplan, 2013] and it plays a crucial role especially in the sectors where the existing models of innovation are unsuccessful, obsolete or unable to take advantage of the opportunities arising in the environment [Mulgan, Tucker, Ali, Sanders, 2007]. Relating to the Global Opportunity Network's ${ }^{7}$ report [2016] there is a significant and observed shift in global mindset where people transform global and national risks into opportunities offering varied solutions and innovations for social good. Yearly, the Global Opportunity Network's [2017] team selects critical global risks and is touring continents to harvest insights and ideas from thought leaders in several sectors on how to turn the global risks into sustainable opportunities. They inspire academia experts, researchers, scholars, social entrepreneurs and social strategists worldwide to seek new solutions for collective social transformation.

The growing sensitivity towards national and global issues, the number of initiatives to make a change, and the number of available technological tools increase the rapid growth of problem solvers from the millennial generation. The innovation types are as diversi-

Global Opportunity Network was established to identify and understand and seek solutions for global risks through collection of insights of leaders from within business, government and civil society across continents [Global Opportunity Network, 2017]. 
fied as the social needs and vary from sanitation health projects to open source platforms and diverse networks to create new products and services for social good [Kaplan, 2013; UNICEF, 2007]. It results in an emerging phenomena of a new wave of social innovators that transform their ideas into social enterprises tackling social challenges in the area of education, healthcare, human rights or social isolation [The Guardian, 2014].

\section{Social entrepreneurship - overview}

In recent years, social entrepreneurship has received increased recognition from public sector, the population at large as well as from scholars. This growing interest can be explained by at least two arguments. First, the innovativeness of treating social problems that are becoming more and more complex. Second, social entrepreneurship can be seen as a way to reduce the financial dependence on private donations and government funding of socially oriented organizations by using market-based solutions [Bacq, Hartog, Hoogendoorn, Lepoutre, 2011]. Consequently, hybrid models of enterprises have emerged that apply for-profit and non-profit elements such as charities and voluntary groups that establish trading operations to generate income for their social missions, co-operatives/social firms that tackle social exclusion by adopting 'bottom-up' and pluralist approaches to governance and human resource management or businesses that invest or share their surpluses in a 'public interest' or 'fair trade' enterprise [RidleyDuff, Bull, Seanor, 2008.]. As a result, the term 'social enterprise' has become highly contested and it seems that the theories have been grouped into two competing perspectives. The first perspective perceives social enterprises as trading organisations sitting in the middle of a continuum between the pursuit of a social mission (charitable) and trading in a market (private). Another per- spective, however, views social enterprise as a cross-sector trading organisation or activity capable of rebuilding and developing social capital and addressing shortcomings of each sector [ibidem] Last but not least, Borzaga and Defourny [2001] admit that social enterprise cannot be just seen as new development of non-profit sector and social economy but it deserves to be seen as a new entrepreneurship. Therefore, the authors [ibidem] identify social entrepreneurship as innovative economic practices just listed with social dimension embedded in the traditional conceptualisation of the third sector. Taking all theories into consideration, it seems to be challenging to place social enterprises in just one distinct area in current economy. Nevertheless, according to Drayton [Forbes, 2012], the founder of Ashoka, the mainstreaming of social enterprise means its disappearance as a distinct activity, where non-profits now routinely engage in profit-seeking activities, for-profits seek social value through business and charitable activities, and public agencies form partnerships with both [Rangan, Herman, McDonald, 2008]. It causes, however, difficulties in creating precise or agreed upon definition of social entrepreneurship among governments, academics or practitioners in transnational perspective. Therefore, for the purpose of the study, the paper relates to two theories: the first one focuses on commonality among all social initiatives and it understands social venture as a 'problem-solving' enterprise that produces measurable results in the form of changed social outcomes and/ or impacts [Johnson, 2003]; the second definition relates to GEM (Global Entrepreneurship Monitor) and it describes social entrepreneurship as any kind of activity, organisation or initiative that has a particularly social, environmental or community objective [Bosma, Schøtt, Terjesen, Kew, 2016].

Currently, the field is influenced by significant changes in the flow of funding, growing but often untapped philanthropic 
resources, a shift in the role of government, new social investment models as well as shift in commercial activities by socially minded organizations. Undoubtedly, there is a phenomenon within current economy in which various cross-sectoral actors are co-creating the process of social and economic transformation forming diversified types of social entrepreneurial activities embodied in larger ecosystem (Figure 1) [Condie, Cooper, 2015].

\section{Figure 1. Social entrepreneurial ecosystem}

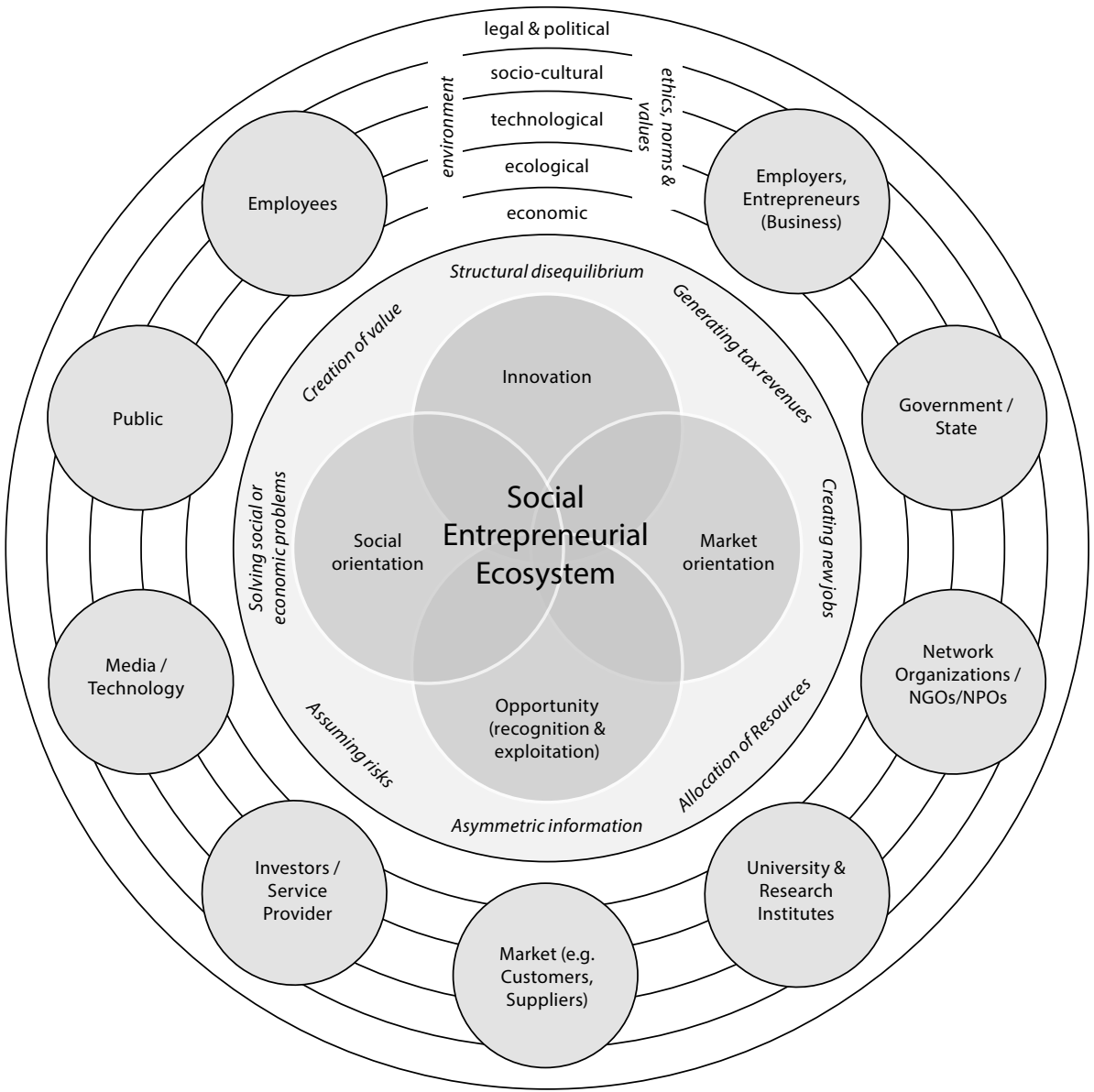

Source: [Condie, Cooper, 2015].

The Figure 1. based on recent social science research of over 80 urban social entrepreneurs [ibidem] perfectly presents a larger picture of new perspective on social entrepreneurship involving contexts from different spheres (innovation, social \& market orientation, opportunity recognition \& exploitation) and actors from different sectors ranging from investors, entrepreneurs, government, NGOs to media, technology, universities or research centres. There is more support in the area of social entrepreneurship than even before encouraging many youth individuals to create social ventures and it has already influenced the youth entrepreneurship globally (see section 3 and 4). 


\section{Social entrepreneurship - trends, patters and future directions}

According to the newest comparative report on the basis of 167,793 adults in 58 economies [Bosma, Schøtt, Terjesen, Kew, 2016], social entrepreneurs are starting businesses in all major regions of the world but with notable variations throughout countries and different economic areas.

The early-stage social entrepreneurial activity, measured by the percentage of adults between the age of 18 and 64 who are currently trying to start a social purpose business is at a global average of $3.2 \%$. The statistics indicate lower prevalence of social entrepreneurial activities in comparison to commercial early-stage activities that are at the global average of $7.2 \%$ [ibidem]. Nevertheless, the detected rate is promising in terms of further social entrepreneurship development.

In overall perspective, Australia and the US have the highest ratios of social entrepreneurship activities (11\%). In Australia and the US, one out of 10 individuals are social entrepreneurs. Sub-Saharan Africa is classified as the second economic area with high social entrepreneurial activities including early and post start-up stage. While social entrepreneurship rates are high in sub-Saharan Africa, these economies tend to be characterised by small-scale entrepreneurial activity in general, in terms of employing few people and not having very high levels of sales. Eastern and Western Europe, Latin America and Caribbean, Middle East and South Africa have average levels of social entrepreneurial activities and they are at the third place in the ranking. The last place belongs to South-East Asia with the least amount of social entrepreneurs - at just 3.8\% [ibidem].

The studies indicate various motives of differsified dynamics of social entrepreneurial activities across the globe, from those innovation driven to those necessity driven. It has been unveiled that the areas with the high- est average level of economic welfare and institutional development have the highest ratios of social entrepreneurial activities due to institutional support mechanisms, such as dedicated facilities to support entrepreneurs. As a contrary, the areas at lower levels of economic development have some of the highest rates of necessity-driven entrepreneurship where individuals' social initiatives are driven by needs that emerge from the local community. Interestingly, the findings illustrate that, at lower levels of economic development, new entrepreneurial activities with social goals are more intertwined with those of regular new businesses [ibidem].

In addition, the newest GEM Report [ibidem] presents four crucial patterns. (1) $55 \%$ of social entrepreneurial activities are led by male and $45 \%$ by female 8 . (2) $38 \%$ of the world's social entrepreneurial ventures rely on government funding. The rest relay on, inter alia, private funds, banks, investors and online crowdfunding. (3) The majority of social enterprises in most economies around the world across all economies are market based rather than non-market based (4) but between 50 and $70 \%$ of operational social entrepreneurs are 'value creators' where generating value to society and environment is more important than financial value.

Besides the observed growth in social entrepreneurial activities globally, the experts from the Harvard Business School [Rangan, Herman, McDonald, 2008] admit that the direction of social entrepreneurship development remains on the brink of several possible futures, including consolidation, entrepreneurial growth, and expressive experimentation. In the consolidation scenario, funding will keep growing and organizations will compete for resources by demonstrating performance. The sector will consolidate, with

\footnotetext{
This gender gap in social entrepreneurial activity is significantly smaller than the roughly 2:1 gender gap in commercial entrepreneurial activity [Bosma, Schøtt, Terjesen, Kew, 2016].
} 
some efficient organizations gaining scale, some merging and then growing, and some failing to achieve either scale or efficiency and eventually shutting down. The entrepreneurial scenario predicts that the existing and new enterprises will apply strategies to achieve and demonstrate performance, improving efficiency and effectiveness and attracting innovative funding strategies and new entrepreneurial models. In the expressive scenario rather than focusing exclusively on performance, funders and organizations may view their investment as an expressive civic activity with an emphasis on employing concrete measures of impact or efficiency. In this scenario, funding will flow as social entrepreneurs experiment with new models based on a range of individual priorities and relationships. The scenario that unfolds over the next 20 years will depend largely on the ability of social enterprise leaders to make a leap forward in thought and action to capitalize on the abundant potential for social change [ibidem]. It seems, additionally, that the future of social entrepreneurship highly depends on the young entrepreneurs aged between 18-34 as statistically they contribution to social entrepreneurial activities is the highest (see section 4, Figure 2).

\section{New generation of social entrepreneurs}

A significant number of discussions highlighted the vital role of a new wave of young individuals from millennial generation joining the area of social entrepreneurship. Millennials massively enter the labour market reshaping the global economy and the way how business is conducted [Millennial Center for Social Entrepreneurship, 2016]. This generation brings a youthful energy, a technological twist and a different perspective to entrepreneurship and community service as they venture out in new ways to address local and world issues [Michigan State University, 2015].

Figure 2. Age of social entrepreneurs, and commercial entrepreneurs, by phase

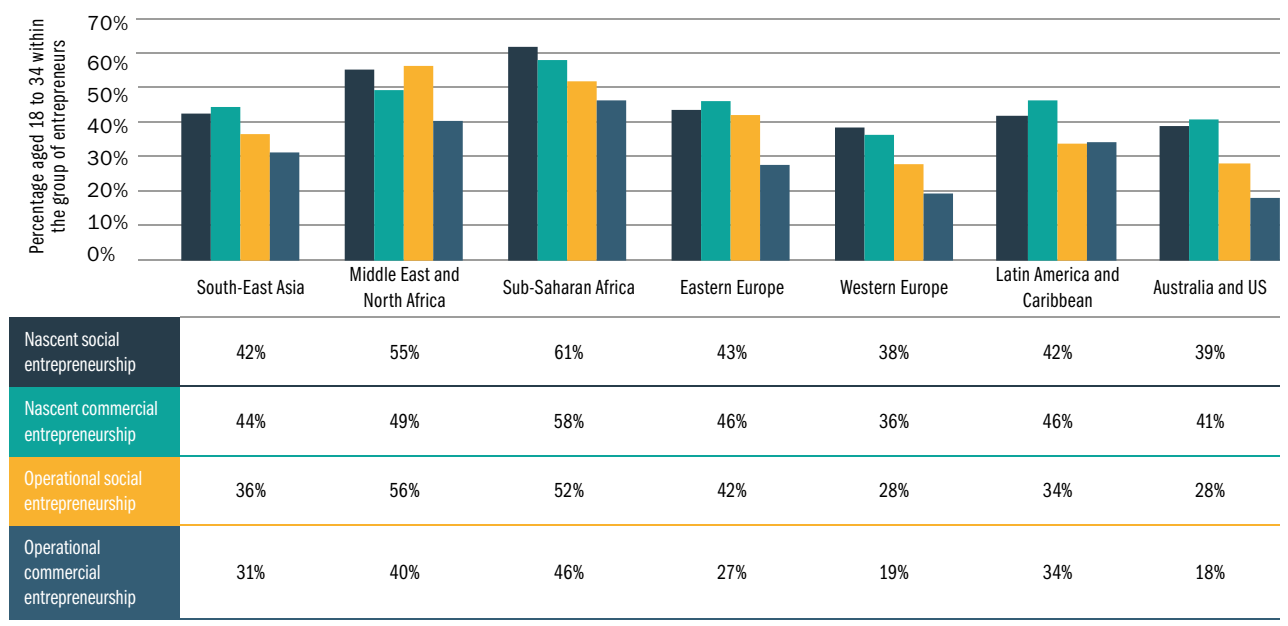

Source: [Global Entrepreneurship Monitor, 2015].

The newest report of Global Entrepreneurial Monitor [Bosma, Schøtt, Terjesen, Kew, 2016] shows that youth entrepreneurs at the age of 18-34 are more likely to set up socially oriented business than commercial ventures. The statistic shows that the rate of 
the young (at that particular age range) leading social entrepreneurial activities at operation stage (post start-up stage) exceeds the number of those involved in regular business, which unveils a new phenomenon in the global youth entrepreneurship (see Figure 2).

The discovered trend has influenced more focus on the youth education and professional development in the area of social entrepreneurship. In the Ashoka network [Ashoka, 2013] about 700 of the 3,000 social entrepreneurs already work directly with youth to help them develop entrepreneurial skills to flourish in the social entrepreneurial area and to solve critical global or national issues. The developing sector of social entrepreneurship needs talented individuals who have the ability to turn the idea into profitable and sustainable long-term business venture [Millennial Center for Social Entrepreneurship, 2016].

New generation surrounded by online environment has an ability to connect with cultures across the world, making it easier to understand and quickly respond to various global problems. Technology provides all sorts of tools ranging from solution design, advertisement to sharing, collaborating or networking. The technologically emboldened generation, with attention to capital, financial sustainability and access to community or infrastructure, seems to have no barriers in creativity and innovation [Kaplan, 2013; World Economic Forum, 2015]. Nevertheless, those who go into the direction of social innovation differ in terms of motivation to engage in social activities: social entrepreneurs demonstrate a socio-moral motivation in their entrepreneurial initiatives [Bacq, Hartog, Hoogendoorn, Lepoutre, 2011]. Shaw and Carter [2007, as cited by Bacq, Hartog, Hoogendoorn, Lepoutre, 2011], found that social entrepreneurs are more likely to be motivated by social aims, such as to affect change and make a difference, to meet local needs or to tackle a social issue. Dees [as cited in Johnson, 2003] identifies five criteria that social entrepreneurs possess: adopting a mission to create and sustain social value; recognizing and relentlessly pursuing new opportunities to serve that mission; engaging in a process of continuous innovation, adaptation and learning; acting boldly without being limited by resources currently in hand; and exhibiting a heightened sense of accountability to the constituencies served and to the outcomes created. However, the today's profile of millennial social entrepreneurs expands the previous descriptions and majority of the specific traits are confronted with functional questions on how millennials acquire resources for their social businesses, how they allocate resources, how they build successful organizations, and how they achieve impact from social investment [Rangan, Herman, McDonald, 2008] A recent review of social entrepreneurship literature showed that young social entrepreneurs are likely to share a series of behavioural characteristics with the commercial entrepreneurs, such as: the ability to detect opportunities, the drive to innovate, the willingness to bear risk and the display of proactive behaviour towards survival, growth and serving the market [Bacq, Hartog, Hoogendoorn, Lepoutre, 2011]. Nevertheless, majority of early developing social entrepreneurs have difficulty to make their ventures sustainable. Therefore, many countries (especially those at higher level of economic development) offer supportive mechanism and mentoring, coaching or co-working with experts at different stages of the social enterprise development [Bosma, Schøtt, Terjesen, Kew, 2016].

\section{Exploratory research of new generation of social entrepreneurs}

The performed pilot research is based on narrative and qualitative analysis exploring the profile of new generation of social entrepreneurs. The analysis is an elabora- 
tion attempt on already released extensive exploratory research of new generation social enterprises worldwide including 14 European countries and 5 overseas performed by Benadusi and Sapienza [2012] within EFESElIS project - Enabling the Flourishing and Evolution of Social Entrepreneurship for Innovation and Inclusive Societies [EFFESEIS, 2016]. The previous analysis of a sample of social ventures emerged in the particular time frame (20062012) provided broad and valuable overview of the main organizational characteristics, forms of diffusion and identify-based specificities that contribute to shaping the new generation of social entrepreneurs. However, taking into consideration the field dynamics, there is constant and further observation needed to detect the evolution of the pathways of social entrepreneurship. Therefore, the current research is exploratory and introductory in the area of new generation of social enterprises emerged between 2013 and 2017 expanding the time frame of the previously performed analysis (2006-2012) [Benadusi, Sapienza, 2012].

The research explores 71 new generation of social enterprises worldwide (see Appendix) selected from the total 120 social enterprises presented by Forbes in four yearly reports. The selection has been on the basis of two fundamental criteria: the age of the co-founders/founders (18-30) and the time frame of the social enterprises emergence (2013-2017).

The research methodology is a compilation of two main approaches:
(1) part of EFESEIIS [ibidem] narrative methodology and analysis approach (mix of data collection techniques, desk analysis collection of relevant promotional materials, website information, biographical reviews of founders' life story) and core variables:

- innovation type - new technology, platforms, applications, products, service, scientific processes etc.,

- revenue capacity - market oriented, customer driven, institutional fund raising, donation or integrated models,

- field of operation - specific sector of intervention,

- outreach capacity - national or global social impact,

- specific ecosystems - patterns in market, society, environment and founders' life stories, experiences, background etc. influencing the social enterprise emergence;

(2) social entrepreneurship ecosystem model that categorize the chosen variables [Condie, Cooper, 2015]:

- innovation - innovation type,

- social orientation - field of operation, outreach capacity,

- market orientation - revenue capacity,

- opportunity recognition/pattern - specific ecosystems.

The compilation provides sample of variables, tool for its analysis and exemplary categorization model (see Figure 3). 
Figure 3. Data collection and categorization

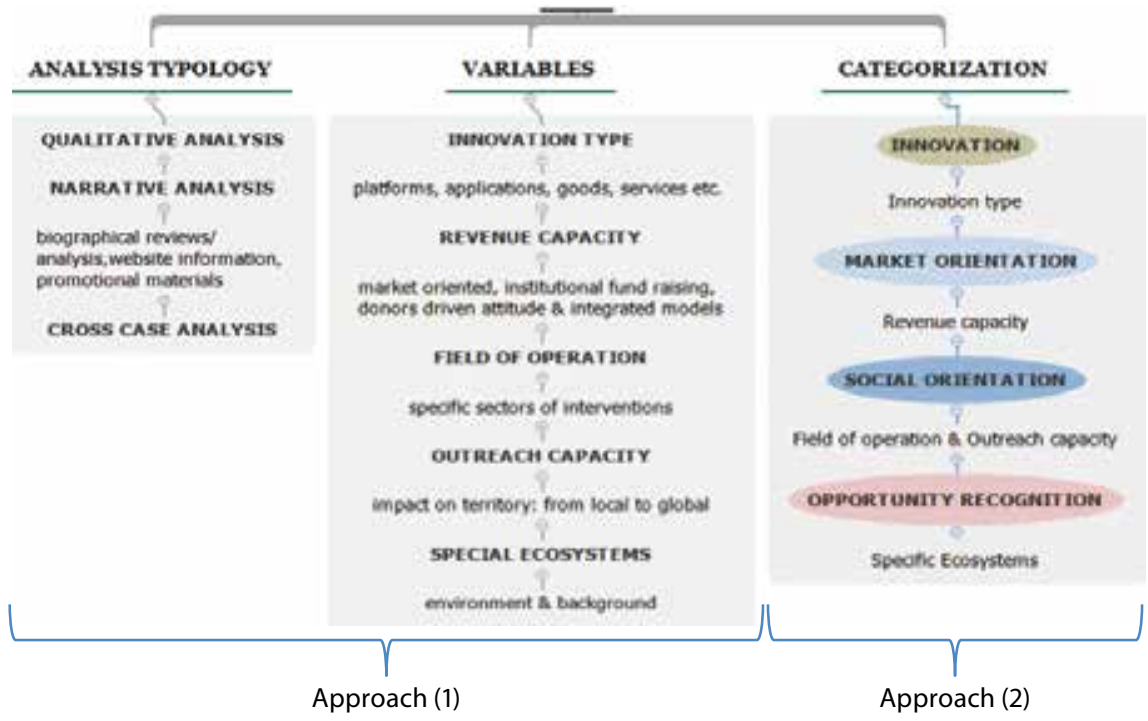

Source: own elaboration on the basis of EFESEIIS cross case analysis approach [Benadusi, Sapienza, 2012] and social entrepreneurial ecosystem model [Condie, Cooper, 2015].

The collected data have been categorized and analysed on the basis of cross case analysis approach. The analyses identify differences and similarities and effectively synthesize the chosen sample of new generation of social enterprises unveiling leading patterns within specific core areas (innovation, market orientation, social orientation, opportunity recognition). It provides a base for initial assessment of the three previously discussed possible future directions of social entrepreneurship (see section 3 ).

\section{Research findings}

The biographical traits of the selected sample have unveiled that $66 \%$ of the new generation of social entrepreneurs are male and $34 \%$ female in transnational perspective. Majority of them (both male and female) is at the age of 29 (27\%) and at the age of 27 (15\%).

The European sample of 45 new generation of social enterprises has its origins in 14
European countries: UK, Poland ${ }^{9}$, Greece, Germany, Bulgaria, Spain, Austria, France, Netherlands, Sweden, Italy, Switzerland, Ireland and Belgium. 33\% of the analysed social enterprises have been established in UK, 15\% in Germany, 13\% in France and the lasting $39 \%$ in the rest 11 European countries. The majority of the headquarters of the global sample of social enterprises is located in US and the rest in the developing world including Kenya, Botswana, India, Nepal.

The deeper insights into the selected sample of social enterprises have explored four basic and major features shaping the profile of new generation of social entrepreneurs: innovation, social and market orientation and opportunity recognition patterns influencing the formation of the social enterprises. The

\footnotetext{
SOCIAL WOLVES is the go-to platform for creating original social projects and developing skills of the future, see more at http://socialwolves.com/\#/app/home.

FIVE APP is the world's first sign messenger for Deaf people, see more at http://fiveapp.mobi/.
} 
four major categories are determined by various features and factors presented below.

\section{Innovation}

\section{Innovation Type}

The cross-case study analysis of selected social enterprises has unveiled four innovation types: (1) Technology (including platforms, applications, devices, tech products and digital systems), (2) Products (various types but not tech made), (3) Services (including community building and programmes \& trainings), (4) Processes (e.g. scientific processes).

\section{Graph 1. The most frequently chosen innovation types by new generation of social entrepreneurs}

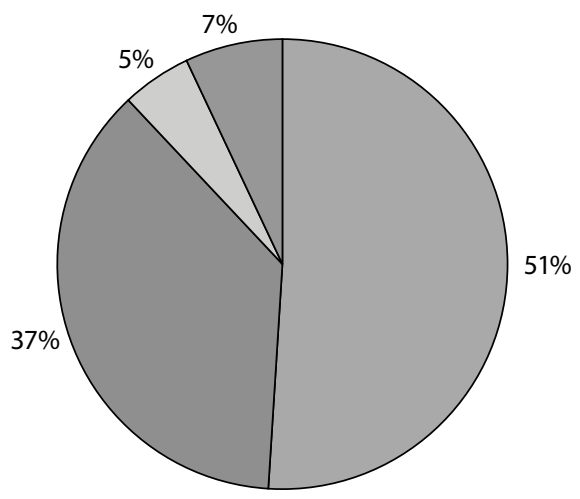

Source: own elaboration.

The technological innovation represents $51 \%$ of the total number of the analysed European and global solutions among young social entrepreneurs. The studies have revealed broad range of technological solutions ranging from platforms navigating people with autism, online job platforms for refugees [REFUGEESWORK, see Appendix], online marketplaces preventing food waste [SPOILER ALERT, see Appendix] to devices for visible impaired [BLINDSHELL, EYRA, see Appendix] or solar powered microclimates [WAKATI, see Appendix] and biosolar leafs [ARBOREA, see Appendix]. Platform and tech products (especially biotechnology products) are the leading solution patterns within technological innovation. The creativity in connecting technological solutions with diversified social issues results in development of assistive technology where around $46 \%$ of technological solutions in Europe and $60 \%$ of technological solutions in global context are devoted to those socially excluded (see more in section: Fields of operation).

Services in a form of community building or programmes or trainings are the second core innovation representing $37 \%$ of all collected solutions. This category offers variety of solution patterns including empowerment, educational, integration or interventional programmes affecting numerous beneficiaries ranging from women entrepreneurs, vulnerable kids, youth, refugees or poor families in developed or developing countries.

Products and processes are the lowest frequency innovation types among young social entrepreneurs and together represent only $12 \%$ in European and global area. The invented products are mainly aimed at child care and education and vary from production of glasses for one dollar for kids in developing countries [ONE DOLLAR GLASSES, see 
Appendix], wooden robot for coding learning [PRIMO TOYS, see Appendix] or books introducing kids to entrepreneurial models [CLEVER TYKES, see Appendix]. Processes in a form of scientific mechanisms are mainly aimed at environment in a form of roof farming [UP TOP ACRES, see Appendix], or process of changing waste feathers into sustainable materials (AEROPOWDER, see Appendix).

\section{Market orientation}

\section{Revenue Capacity}

The market orientation has been mainly assessed on the basis of revenue capacity of the analysed social enterprises in European and global context. The cross case analyses have unveiled two types of revenue capacity: 1) donor driven, fund raising, 2) integrated models - combining market orientation with donor driven and fund raising. None of the selected new generation of social enterprises has been fully market oriented without additional public or societal support. According to the research, the revenue capacity approach is highly dependent from the innovation type and field of operation. Majority of online e-commerce platforms e.g. promotion and selling of rural artisans' products [ENROU, see Appendix] or platforms preventing waste of food or promoting local farmers products [GROW UP URBAN FARMS, FOOD CLOUD, see Appendix] operate on the basis of margins, fees and donors or public-private partnerships. Various programmes and trainings for vulnerable groups are highly publicly supported while tech solutions in a form of devices or products frequently and easily integrate business and social approach as they are more likely to be supported by entrepreneurs or business advisors. The research unveils gradual increase in business activities of all new generation of social enterprises where $48 \%$ of total (European and global) revenue capacity operate in a form of integrated models.

\section{Social orientation}

\section{Field of operation}

The analyses explore three core areas of intervention: 1) society: education, health care and social inclusion, 2) (sustainable) environment: energy, recycling, air pollution, water ecology and farming, 3) support mechanisms for social economy: fundraising, social awareness.

\section{Graph 2. The core fields of operation of new generation of social enterprises}

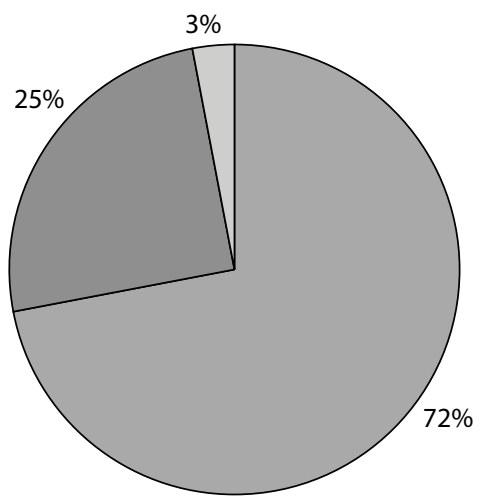


With relation to the analysed data, 51 of 71 social enterprises (72\%) offer solutions for society including improvement in the area of education, health care or social exclusion. Importantly, social exclusion is the prominent subcategory and 32 of 51 of the analysed social enterprises (64\%) focus on issues of specific vulnerable groups (see below). The remaining 19 social enterprises (8\%) are devoted to education and health care support including e.g. knowledge and data store platforms or new digital systems for overall better educational or health performance.

\section{Graph 3. The areas of intervention of new generation of social entrepreneurs}

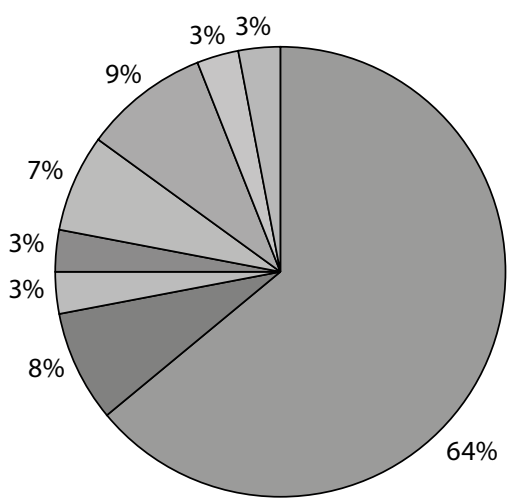

Source: own elaboration.

On the basis of the collected data, it can be assumed that the young generation of social entrepreneurs significantly supports various types of socially excluded groups. In Europe, new generation of social entrepreneurs devote their work to social inclusion of 10 groups: autistic people, young, refugees, deaf people, visually impaired or blind, people with eating disorder, elderly people, poor families or individuals in developed and developing world, kids and women. The global context expands the area of operation by additional 6 examples: people after jail, black kids, artisans from rural communities, homeless, farmers and not qualified at different age. In total, new generation of social entrepreneurs work with or for 16 social groups solving their issues mainly through technological innovation and various intervention or integration programmes.

Accordingly, the environmental protection solutions represent $25 \%$ of the total

\section{SOCIAL INCLUSION}

EDUCATION/HEALTH CARE

SUSTAINABLE ENERGY

AIR POLLUTION

FOOD WASTE

ECOLOGY AND FARMING

CLEAN WATER

SE SUPPORT

number of innovation types and are considered to be the second major field of operation among new generation of social enterprises. The young generation seeks solutions in the area of sustainable energy production (3\%), air pollution (3\%), waste, especially food waste (7\%), ecology and farming (9\%) and access to clean water in developing countries (3\%). Technological savvy and high educational/engineering background of the young social entrepreneurs result in environmental transformations unveiling the strongest intervention in the area of waste, ecology and farming including micro ecosystems or platforms, applications and biotechnological systems for food waste reduction.

The last discovered category relates to support mechanisms for social economy representing the lasting 3\% of total solutions. The small percentage of solutions within this area does not necessary indicate less importance as the offered solutions build extensive 
public-social and private partnerships helping in fund raising, spreading social awareness or blurring boundaries between society, companies, NGOs, charities or associations.

\section{Outreach capacity}

The sample of data allows to observe the scale of social impact of young social entrepreneurs' solutions assessing the tendency to solve mainly local or global issues. In Europe only 10 out of 45 social enterprises solve local issues while the lasting majority of 35 social enterprises reaches global market including $5 \%$ with a focus on the developing world such as Africa, Asia or Latin America. The analysed sample of global social enterprises indicates that 15 out of 26 social enterprises acts in local area and the remaining 17 social enterprises spread their impact into other countries and the developing world (7\%). In total (from European and global perspective), $35 \%$ of social enterprises focus on local issues and $65 \%$ reach global scale where $12 \%$ solves issues in developing world from distance and only $8 \%$ is headquartered in rural areas solving the issues from the local perspectives.

\section{Opportunity recognition}

\section{Special Ecosystems and Backgrounds}

The analysis of the founders' background has allowed to explore the unique recognition patterns, which is highly significant to discover the potential motives and factors that push or pull the new generation to notice and solve social issues. Additionally, the overview of the surrounding ecosystems has allowed to assess the basic factors of opportunity acceleration.

The analysed sample of social enterprises has revealed three recognition patterns: (1) personal background: own story or experience, life philosophy and passion, (2) somebody's story: observations and inspirations, (3) education and scientific research.
The data has unveiled that the personal background is the leading opportunity recognition pattern among young social entrepreneurs in European and global context and it represents $56 \%$ of all discovered patterns. However the personal background is characterized by push and pull factors influencing the opportunity identification. Frequently, push factors (21\%) are connected with negative experience in a form of bad personal story such as being diagnosed with an illness or bad childhood experience or death of family member, which forces young social entrepreneurs to take an action in particular area. The pull factors (35\%) are very often connected with a need of the young generation to express their life philosophy (such as democratization of entrepreneurial sources or equality of opportunities or using technology to create catalysts to unite communities).

The young generation of social entrepreneurs are very frequently inspired to make a social change by observations and/or somebody's stories (28\%). According to the data, traveling to the developing world or volunteering in rural communities are the main core external factors influencing the identification of the area of intervention.

Additionally, $15 \%$ of the young social entrepreneurs has entered the area of social entrepreneurship on the basis of educational background or scientific research. There is a tendency among advanced technological or biotechnological solutions that are mainly discovered through extensive educational programmes and individuals' passion to devote knowledge or science to something purposeful.

The analyses of the specific ecosystems have discovered that young generation of social entrepreneurs are broadly surrounded by seven types of cross-sectoral actors: (1) advisory board: professors, doctors, entrepreneurs, specialists etc.; (2) capital partners: individual investors, enterprises; (3) press: international or global press; (4) incubators: 
coaches and mentors; (5) institutional partners: government or other public institutions; (6) research partners: e.g. technological institutes; (7) social partners: foundation, charities or donors. The share of knowledge, experiences or resources results in co-creation and acceleration of social innovation and socioeconomic change.

\section{Conclusions}

The theoretical review combined with the insights into 71 social enterprises (45 Europe, 26 global, see Appendix) have explored various factors and features shaping the profile of new generation of social entrepreneurs worldwide. The created model of own research and the cross case studies analysis of European and global examples have resulted in extensive comparative studies leading to discovery of two general biographical traits and five key patterns that strongly characterize the whole selected sample of the young social entrepreneurs.

\section{BIOGRAPHICAL TRAITS}

The female component is lower than the male component: $66 \%$ of the new generation of social entrepreneurs are male and $34 \%$ female in transnational perspective. Majority of them (both male and female) is at the age of $29(27 \%)$ and at the age of $27(15 \%)$.

\section{FIVE KEY PATTERNS}

- TECHNOLOGY - technology is the most frequently used innovation type $(51 \%$ of total innovation types, and $27 \%$ are in a form of online platforms);

- SOCIAL ORIENTATION - social exclusion is a leading intervention area ( $64 \%$ of all fields of operation);

- SOCIOECONOMIC BALANCE - growing balance between two models of revenue capacity: donor driven / fund raising (48\%) and integrated models (52\%);
- PUSH AND PULL FACTORS - personal traits and life stories are the main opportunity recognition patterns that push $(21 \%)$ or pull $(35 \%)$ young generation to solve national or global issues;

- SECTORAL PARTNERSHIPS - specific ecosystem of new generation of social enterprises provides support from 7 types of different actors building public-private and social partnerships blurring the sectoral barriers.

Technological savvy and creativity of young social entrepreneurs improves the social and environmental conditions worldwide. The analysis has unveiled that around half of the selected social enterprises uses technology as a tool to unite communities or to solve socioeconomic issues in transnational perspective. The new generation of social entrepreneurs seeks innovative solutions to support 16 vulnerable groups e.g. autistic kids, homeless and disabled people, refugees or rural communities. The environmental protection solutions represent a quarter of total number of innovation types where food waste, ecology and farming are the main areas of intervention. Interestingly, the motives of the unique solutions fulfilling social, economic or environmental gaps are hidden in three recognition patterns: personal experience and believes (56\%), education/scientific research (15\%) or observations and discovery of somebody's story (28\%).

The exploratory research findings, commonalities and unique patterns allow to assess possible future directions of the new generation of social entrepreneurship with relation to the Harvard Business School's theory [2008] (see section 2). The analysed sample, however, has limitations in a form of number of analysed entities or variables types and lack of primary research. Nevertheless, it can be assumed that young social entrepreneurs become more entrepreneurial applying more frequently integrated models connecting business activities with public 
and social support. Additionally, the growing number of individual investors, business capital partners, advisors, specialists or coaches equip young social entrepreneurs with resources and knowledge which might result in experiments in new approaches and models or consolidation of some of those already active in socioeconomic area. Consequently, the future direction of young social entrepreneurs might be a compilation of entrepreneurial, consolidation and expressive scenarios where young social entrepreneurs will be challenged to maintain or increase or experiment with new solutions and business approaches in social area facilitating their

\section{Literatura}

Andersson T., Curley G.M., Formica P. (2010). Knowledge-Driven Entrepreneurship: The Key to Social and Economic Transformation. New York: Springer.

Ashoka (2017). Ashoka's Vision Realizing the 'Everyone Changemaker'World.

Ashoka (2013). The 10th annual Skoll World Forum, https://www.ashoka.org/en/story/10-things-ilearned-skoll-world-forum-2013.

Bacq S., Hartog C., Hoogendoorn B., Lepoutre J. (2011). Social and Commercial Entrepreneurship: Exploring individual and organizational characteristics. Zoetermeer, The Netherlands.

Benadusi M., Sapienza R. (2012). "New Generation of Social Entrepreneurs", Explanatory Case Study Series, EFESEIIS.

Borzaga C., Defourny J. (eds.) (2001). The emergence of social enterprise. London: Routledge.

Bosma N.S., Schøtt T., Terjesen S.A., Kew P. (2016). Global Entrepreneurship Monitor 2015 to 2016: Special Report on Social Entrepreneurship. Global Entrepreneurship Research Association, www.gemconsortium.org.

Condie J. Cooper. A.M. (2015). Dialogue of Sustainable Urbanization: Social Science Research and Transition to Urban Contexts. Penrith, N.S.W.: University of Western Sydney.

EFESEIIS (2016). Enabling the Flourishing and Evolution of Social Entrepreneurship for Innovative and Inclusive Societies, http://www.fp7-efeseiis.eu/.

Forbes (2012). Five Predictions For the Future of Social Entrepreneurship, https://www.forbes.com/sites/ ashoka/2012/11/19/five-predictions-for-the-futureof-social-entrepreneurship/\#422e57c3508d. personal passions, stories and values into social innovation but with public and entrepreneurial support from the expanding social entrepreneurial ecosystem.

There are, however, many aspects that remains empirically unexplored through the paper limitations such as country specific patterns of the new generation of social entrepreneurs, specific factors accelerating/limiting young social entrepreneurs per countries, or comparison between social and commercial entrepreneurs from millennial generation. The identified gaps might be a recommendation for further research.

Forbes Europe (2016). 30 under 30 Social Entrepreneurs in Europe, https://www.forbes.com/30-under-30-europe-2016/social-entrepreneurs/\#7cd8c8f5bd5b.

Forbes Europe (2017). 30 under 30 Social Entrepreneurs in Europe, https://www.forbes.com/30-under-30-europe-2017/social-entrepreneurs/\#15ed99d2154d.

Forbes Global (2016). 30 under 30 Social Entrepreneurs, https://www.forbes.com/30-under-30-2016/ social-entrepreneurs/\#90d87574a320.

Forbes Global (2017). 30 under 30 Social Entrepreneurs, https://www.forbes.com/30-under-30-2017/ social-entrepreneurs/\#26fd3c4a1332.

Global Opportunity Network (2017). Report, http:// globalopportunitynetwork.org/the-2017-globalopportunity-report.pdf.

GEM Consortium (2017a). What is GEM?, http://www. gemconsortium.org/.

GEM Consortium (2017b). Entrepreneurs Worldwide turn their focus on doing good, http://gemconsortium. org/about/news/34.

Johnson S. (2003). Young Social Entrepreneurs in Canada. Alberta: Canadian Centre for Social Entrepreneurship, School of Business, University of Alberta, http:// www.ub.edu/emprenedoriasocial/sites/default/ files/Young\%20Social\%20Entrepreneurs\%20in\%20 Canada.pdf.

Kaplan M.J. (2013). Growing the Next Generation of Social Entrepreneurs. Ian Axford Fellowship in Public Affairs, Fullbright New Zealand.

Michigan State University (2015). Social entrepreneurs: New generation, http://msue.anr.msu.edu/ news/social_entrepreneurs_a_new_generation.

Millennial Center for Social Entrepreneurship (2016). A Deeper Look at Social Entrepreneurship: Key Trends in 2016 (And Beyond), http://www.scu-socialentrepreneurship.org/new-blog/2016/7/7/a-deeper- 
look-at-social-entrepreneurship-key-trends-in2016-and-beyond.

Mulgan G., Tucker S., Ali R., Sanders, B. (2007). Social Innovation: what it is, why it matters, how it can be accelerated, http://youngfoundation.org/publications/social-innovation-what-it-is-why-it-mattershow-it- can-be-accelerated.

Nicholls A., Murdock A., eds. (2012). Social Innovation: Blurring Boundaries to Reconfigure Markets. Palgrave Macmillan.

Rangan V.K., Herman, B.L., McDonald S. (2008). "The Future of Social Enterprise", Harvard Business School Working Paper, No. 08-103, http://www.hbs. edu/faculty/Publication\%20Files/08-103.pdf.

Ridley-Duff R., Bull M., Seanor P. (2008). Understanding Social Enterprise: Theory and Practice. SERC Conference, 5th UK SOCIAL ENTERPRISE RESEARCH CONFERENCE SERC $2008-26$ \&27 June.

\section{Appendix}

\section{(GLOBAL)}

ANSEYE PAU AYITI: http://anseyepouayiti.org/en/ ASPIRE FOOD GROUP: http://www.aspirefg.com/ BAYES IMPACT: http://www.bayesimpact.org/ DRIVE CHANGE: http://drivechangenyc.org/ EDENWORKS: http://edenworks.com/

ENROU: https://enrou.co/

GOORU: https://www.gooru.org/welcome/ HUNGRY HARVEST: http://www.hungryharvest.net/ KIDOGO https://www.kidogo.co/ KISAN NETWORK: http://kisannetwork.in/ LUCKY IRON FISH: http://www.luckyironfish.com/ MADE IN BROWNSVILLE: http://madeinbrownsville. org/

MORINGA SCHOOL: http://moringaschool.com/ MOUNTAIN RESILIENCY https://www.mountainresiliency.org/

NEW STORY: https://www.newstorycharity.org/ PROFOUND GENTLEMEN: http://profoundgentlemen.org/ RORUS: https://www.rorusinc.com/

SHRI: https://www.sanrights.org/ SOKO: https://shopsoko.com/pages/about SPOILER ALERT: https://www.spoileralert.com/ STREETCRED: https://www.mystreetcred.org/ THINK OF US http://thinkof-us.org/ UNREASONABLE INSTITUTE: https://unreasonableinstitute.org/ UP TO ACRES: http://uptopacres.com/index.html WE THRIVE: https://wethrive.net/ YOUNG 1OVE: http://www.younglove.org/

\section{(EUROPEAN)}

AEROPOWDER: http://www.aeropowder.com/
Skoll World Forum (2017). Mission, http://skoll.org/ skoll-world-forum/.

The Guardian (2014). The new social entrepreneurs: young tech savvy and improving the world, https:// www.theguardian.com/social-enterprise-network/2014/feb/05/young-tech-savvy-doing-goodnew-generation-social-entrepreneurs.

UNICEF (2007). Adolescents and Civic Engagement: Social Entrepreneurship and Young People. New York: United Nations Children's Fund (UNICEF).

World Economic Forum (2015). New Generation of Social Entrepreneurs, https://www.weforum.org/ agenda/2015/02/the-next-generation-of-socialentrepreneurs/.

World Economic Forum (2017). Mission, https:// www.weforum.org/about/world-economic-forum.

AGRICOOL: http://www.agricool.co/

APRENDICES VISUALES http://www.aprendicesvisuales.org/en/about-us/

ARBOREA: http://arborea.io/

AWAMO: http://awamo.com/

BEATFREEKS: http://www.beatfreeks.com/

BLINDSHELL: https://www.blindshell.com/

BRIDGE FOR MILLION: https://bridgeforbillions.org/ about-us.html

CENTRE FOR EFFECTIVE ALTRUISM https://www.centreforeffectivealtruism.org/

CLEVER TYKES http://clevertykes.com/

DAYCAPE: https://www.daycape.com/

E-SOLIDAR https://www.esolidar.com/how-it-works

EDPUZZLE: https://edpuzzle.com/

EMPOWHER: https://www.empowherretreat.com/

ETHELON: http://www.ethelon.org/

EYRA: https://eyra.io/

FARMHOPPING: https://farmhopping.com/

FIVE APP: http://fiveapp.mobi/

FOOD CLOUD: https://food.cloud/

FRONTLINE: https://www.centreforeffectivealtruism. org/

GREEN CITY SOLUTIONShttp://greencitysolutions. de/english/

GREENELY: https://greenely.com/

GROWUP URBAN FARMS: http://growup.org.uk/

INTERNS GO PRO: http://www.internsgopro.com/en/ home/

JOURVIE http://www.jourvie.com/en

LENSATIONAL: http://www.lensational.org/

LIBROMAT: http://www.libromat.com/about.html

NATAKALLAM: https://natakallam.com/ 
ONE DOLLAR GLASSES: https://www.onedollarglasses. org/

OORJA http://www.oorjasolutions.org/\#about-us PAPERHIVE: https://paperhive.org/

PHYSEE: http://www.physee.eu/powerwindow/ PRIMO TOYS: https://www.primotoys.com/ REFUGEES WORK: https://www.refugeeswork.at/ SEED STAR WORLD: https://www.seedstarsworld. com/

SELFAPHY: http://www.selfapy.de/

SIMPRINTS: https://www.simprints.com/
SINGA: https://www.singafrance.com/

SOCIAL WOLVES: http://socialwolves.com/\#/app/ home

SPEAKSET: https://www.speakset.com/

STARTUPBOAT: http://www.startupboat.eu/

THE 4FRONT PROJECT: http://4frontproject.org/

UBER DER TELLERRAND: https://ueberdentellerrandkochen.de/

VRATSA SOFTWARE COMMUNITY: http://school.vratsasoftware.com/en/

WAKATI: http://www.wakati.co/

\section{Nowe pokolenie przedsiębiorców społecznych - studium przypadku przedsiębiorstw społecznych pokolenia millenialsów}

Streszczenie: Intensywny rozwój ekonomii społecznej jest coraz częściej kształtowany przez tzw. pokolenie millenialsów. Najnowsze raporty dotyczące przedsiębiorczości społecznej zauważają wzrost zaangażowania młodych przedsiębiorców w rozwój inicjatyw społecznych w skali globalnej. Artykuł podejmuje próbę weryfikacji kluczowych cech omawianego zjawiska oraz utworzenia profilu młodego przedsiębiorcy społecznego. W tym celu autorka analizuje studium przypadku wybranych przedsiębiorstw społecznych założonych przez młodych przedsiębiorców poniżej 30. roku życia. Próba obejmuje 71 podmiotów społecznych działających w Europe i na świecie. Badanie jakościowe dokonuje charakterystyki młodych przedsiębiorców społecznych według poszczególnych kategorii, m.in.: głównych typów innowacji społecznych, rodzaju wpływu społecznego i jego skali (globalna lub lokalna), orientacji rynkowej oraz specyficznych aspektów biograficznych i motywów działania w obszarze ekonomii społecznej. Badanie wykryło m.in. wzrost orientacji rynkowej, liczne technologiczne rozwiązania głównie w obszarze wykluczenia społecznego oraz zbliżone wartości czynników zachęcających i zmuszających (tzw. 'pull/push factors') mających wpływ na tworzenie się podmiotów ekonomii społecznej wśród młodych przedsiębiorców w wymiarze międzynarodowym.

Słowa kluczowe: nowe pokolenie, przedsiębiorca społeczny, przedsiębiorczość społeczna, innowacja społeczna.

\section{Prawa autorskie i licencja / Copyright and License}

Artykuł opublikowano na licencji Creative Commons

Uznanie autorstwa - Użycie niekomercyjne - Bez utworów zależnych 3.0 Polska http://creativecommons.org/licenses/by-nc-nd/3.0/pl/

This article is published under the terms of the Creative Commons Attribution - NonCommercial - NoDerivs (CC BY-NC-ND 3.0) License http://creativecommons.org/licenses/by-nc-nd/3.0/ 